\title{
PENDIDIKAN BERBASIS HAK ANAK Mengikis Praktik Budaya Kekerasan di Institusi Pendidikan
}

\author{
Ahmad Syamsul Arifin \\ PGMI FITK UIN Sunan Kalijaga Yogyakarta \\ Email : houseofhappiness@gmail.com
}

\begin{abstract}
Abstraks
Konvensi Hak Anak (KHA) telab memberikan pengakuan atas eksistensi anak sebagai subyek bak asasi manusia (HAM). Sebanyak 193 negara telab turut serta dalam meratifikasi Konvensi tersebut. Hal ini berarti pula, babwa sebanyak 193 telab menerima kewajiban untuk mengambil semua langkab-langkab legislatif, administratif, sosial, dan pendidikan secara layak untuk melindungi anak-anak dari semua bentuk-bentuk dan manifestasi kekerasan. Kendati ratifikasi KHA telab menunjukkan universalitas, namun perlindungan anak dari kekerasan, eksploitasi, dan penyalahgunaan kekuasaan (children's protection from violence, exploitation, and abuse) masib sangat lemah, termasuk di lembaga pendidikan. Anak sebagai bagian integral dari komunitas seringkali dijadikan sebagai obyek segala bentuk dan manifestasi kekerasan. Penghukuman secara fisik (corporal punishment) dan merendabkan martabat anak masib sering kali kita dapati praktiknya di sejumlab lembaga pendidikan. Alhasil, banyak anak mengalami trauma, ketakutan dan merasa "tidak aman" saat belajar atau ke sekolah. Kebutuhan untuk meroujudkan pendidikan yang aman, ramah dan bersahabat berbasis pada bak anak merupakan suatu kebutuban yang mendesak selain sebagai wujud pengakuan eksistensi anak oleb negara, akan tetapi juga sebagai perwujudan komitmen negara untuk menjalankan mekanisme pengamanan dan penjaminan atas bak-bak pendidikan anak yang baik, tepat, berkualitas, dan aman.
\end{abstract}

Kata kunci: Pendidikan Berbasis Hak Anak, Kekerasan, Anak, Lembaga Pendidikan

\section{Abstract}

Convention on the Rights of the Child (CRC) bas been giving recognition to the existence of children as subjects of human rights (HAM). A total of 193 countries have participated in the ratification of the Convention. This means, too, 
that as many as 193 bave accepted the obligation to take all appropriate legislative, administrative, social and proper education to protect children from all forms and manifestations of violence. Despite the ratification of the CRC has demonstrated the universality, but the protection of children from violence, exploitation, and abuse of power (children's protection from violence, exploitation, and abuse) is still very weak, including in educational institutions. Child as an integral part of the community is often used as the object of all forms and manifestations of violence. Physical punishment (corporal punishment) and degrading the child is still often we find the practice in a number of educational institutions. As a result, many children are traumatized, frightened and felt "unsafe" when learning or to school. The need to realize the education of safe, welcoming and friendly based on the rights of children is an urgent need than as a form of recognition of the existence of the child by the state, but also as the embodiment of the country's commitment to carry out security mechanisms and guarantees for the educational rights of children are good, precise, high quality, and safe.

Keywords: Child Rights-Based Education, Violence, Child, Educational Institutions

\section{PENDAHULUAN}

Kekerasan sangat dekat dengan kehidupan anak. Anak-anak sudah diperkenalkan dengan berbagai bentuk-bentuk kekerasan, mulai dari kekerasan fisik, verbal, hingga seksual sejak usia dini. Kekerasan terhadap anak dapat terjadi dimanapun, baik di rumah atau di lingkungan tempat mereka tinggal dan bersosialisasi termasuk di sekolah. Bahkan tidak jarang, pada sejumlah kasus sebagian besar pelaku kekerasan adalah orang-orang yang memiliki hubungan kedekatan dan yang seharusnya bertanggung jawab melindungi mereka, seperti orang tua, kakek, paman bahkan guru mereka di sekolah.

Pada pertengahan tahun 2014 misalnya, sebuah berita yang kurang mengenakkan datang kembali dari dunia pendidikan yakni berita tentang terbongkarnya sebuah kasus besar tindak pelecehan seksual disertai dengan tindak kekerasan yang terjadi di salah satu sekolah elit di Jakarta dan diduga melibatkan sejumlah staf pengajar di sekolah tersebut dan kini kasus tersebut telah disidangkan di pengadilan. Tidak kalah menghebohkan adalah peristiwa yang terjadi pada awal bulan Maret yang lalu tentang perlakukan kasar salah seorang oknum guru SD di Manado yang memaksa salah seorang anak didiknya untuk memungut sampah dengan mulutnya. Oknum guru tersebut juga disinyalir telah melakukan sejumlah tindak "pendisiplinan" kepada sejumlah 
anak didiknya dengan disertai tindak kekerasan dan aksi pemukulan. Tidak berhenti di situ, sejumlah kasus tindak kekerasan, seperti tawuran, bulliying, perpeloncoan dan lain-lain terus menghiasi headline di sejumlah media, baik cetak, elektronik dan online.

Tidak hanya memilukan, kasus-kasus kekerasan terhadap anak di dunia pendidikan semakin mempersuram wajah pendidikan Indonesia. Banyaknya kasus kekerasan yang dialami oleh anak-anak yang terjadi di dunia pendidikan bisa jadi dianggap sebagai salah satu indikator buruknya kualitas perlindungan dan pemenuhan hak anak terhadap pendidikan yang layak, ramah dan "bersahabat". Ibarat fenomena gunung es, kasus-kasus di atas hanya lah yang tampak di permukaan. Masih banyak tindak kekerasan dalam dunia pendidikan yang tidak tampak. Bentuk-bentuk penghukuman fisik (corporal punishment) dengan dalih untuk mendidik atau mendisiplinkan siswa seperti dilempar dengan kapur dan penghapus papan tulis, dengan mistar besi panjang, lari mengelilingi lapangan upacara, hingga tindak pemukulan masih sering kita dapati praktinya. Bahkan, sekolah kini juga menjadi ajang praktek kekerasan seksual yang dilakukan oleh murid laki-laki kepada murid perempuan, demikian pula guru terhadap anak-anak didiknya. ${ }^{1}$ Wajar jika kemudian sebagian pihak beranggapan bahwa sekolah kini dianggap sebagai tempat yang tidak aman bagi anak. Sekolah yang seharusnya menjadi tempat perlindungan dan sumber pengetahuan telah berganti wajah sebagai tempat yang menakutkan bagi anak. ${ }^{2}$

\section{PEMBAHASAN}

\section{Budaya Kekerasan Anak di Institusi Pendidikan}

Kekerasan telah menjadi bagian dari perjalanan sejarah kehidupan dan peradaban umat manusia. Usianya adalah setua sejarah dan peradaban itu sendiri. Kekerasan merupakan fenomena universal yang tidak dibatasi oleh ruang dan waktu. Kekerasan sudah dipraktikkan oleh manusia dalam berbagai dimensi ruang, waktu, tahapan dan kategori. Tidak seorang pun yang luput dari tindak kekerasan dalam berbagai bentuk dan manifestasinya. Kekerasan telah menjadi gejala mondial. Tiap hari, berbagai tema dan isu kekerasan telah mendominasi sejumlah peristiwa

${ }^{1}$ Lihat: Arna, Antarini, 2005. Analisis Hasil Konsultasi Anak Regional dan Nasional: Kekerasan Terhadap Anak, Jakarta: YPHA.

${ }^{2}$ Susanto, alah seorang komisioner KPAI bidang pendidikan, melontarkan sebuah pernyataan kepada wartawan dengan menyatakan bahwa sekolah saat ini bukan tempat yang aman bagi anak, "Fenomena punishment bermuatan kekerasan masih terjadi. Masa orientasi siswa baru belum steril dari kekerasan", Lihat: Komaruddin Bagja Arjawinangun, "Kini Sekolah Bukan Tempat Aman untuk Anak", http://metro.sindonews.com/read/936157/31/kinisekolah-bukan-tempat-aman-untuk-anak-1418308935 diakses 1 Maret 2015, pukul: 13.00 WIB 
dan berita di surat kabar dan televisi, media online, karya-karya sasta, dan film. Lebih jauh, akse-aksi kekerasan tersebut bahkan "sengaja" diciptakan, diprovokasi, dikomersialisasikan, dan "dibudayakan" sehingga tercipta budaya kekerasan atau budaya yang menghasilkan kekerasan. Oleh karena berlangsung secara terus menerus, turun menurun, dan setiap saat, maka manusia menjadi semakin tidak peka bahkan mati rasa terhadap berbagai gejala tindak kekerasan, dan bahkan menganggap berbagai tindak kekerasan tersebut sebagai bentuk kewajaran.

Galtung membagi tipologi kekerasan menjadi 3 (tiga) bentuk kekerasan yaitu kekerasan langsung, struktural dan kultural. Kekerasan langsung dianalogikan sebagai sebuah peristiwa; kekerasan struktural sebagai sebuah proses; sedangkan kekerasan kultural sebagai suatu kondisi yang bersifat permanen. Kekerasan kultural merupakan strata yang paling dasar dan sumber inspirasi bagi kekerasan struktural dan kekerasan langsung. Strata berikutnya kekerasan struktural berupa ritme-ritme kekerasan yang melokal dan merupakan pola-pola dari kekerasan kultural. Puncaknya, kekerasan yang tampak oleh mata berupa kekerasan langsung yang dilakukan oleh manusia terhadap yang lain. ${ }^{3}$

Kekerasan langsung termanifestasi dalam perilaku, misalnya pembunuhan, pemukulan, intimidasi, penyiksaan. Kekerasan struktural atau kekerasan yang melembaga termanifestasi dalam konteks, sistem, dan struktur, misalnya diskriminasi dalam pendidikan, pekerjaan, kesehatan. Kekerasan struktural ini juga akan berdampak pada munculnya kemiskinan, ketidakadilan sosial, dan alienasi atau peniadaan individual karena proses penyeragaman warga Negara. ${ }^{4}$ Kekerasan kultural termanifestasi dalam sikap, perasaan, dan nilai-nilai yang dianut dalam masyarakat misalnya, kebencian, ketakutan, rasisme, seksisme, ketidaktoleranan. ${ }^{5}$

Konsep dan istilah budaya kekerasan merupakan konsekuensi makin luas dan kompleksnya tindak kekerasan. Berbagai metode dan alasan pembenaran dicari untuk melegitimasikan tindak kekerasan. Bahkan lembaga- lembaga politik telah mensahkan dan melembagakan kekerasan sebagai alat pemeliharaan tertib sosial $\{$ (social order). Inilah yang menghasilkan apa yang disebut sebagai kekerasan struktural, yaitu kekerasan yang digunakan oleh struktur kekuasaan yang dapat berupa aparat, tentara, pemerintah, dan birokrasi.

Sejatinya, tidak ada seorang pun yang menghendaki kekerasan, bahkan sebaliknya semua menginginkan kekerasan itu diakhiri dengan segera dan

${ }^{3}$ Johan Galtung, Studi Perdamaian: Perdamaian dan Konflik Pembangunan dan Peradaban, (Surabaya: Pustaka Eureka, 2003), hal. 438.

${ }_{4}^{4}$ Justin Sihombing, Kekerasan terhadap Masyarakat Marjinal, (Yogyakarta: Penerbit Narasi 2005), hal. 8 - 9

${ }^{5}$ Simon Fisher, et.al, Mengelola Konflik: Keterampilan \& Strategi untuk Bertindak, (Jakarta: The British Council, 2001), hal. 10 


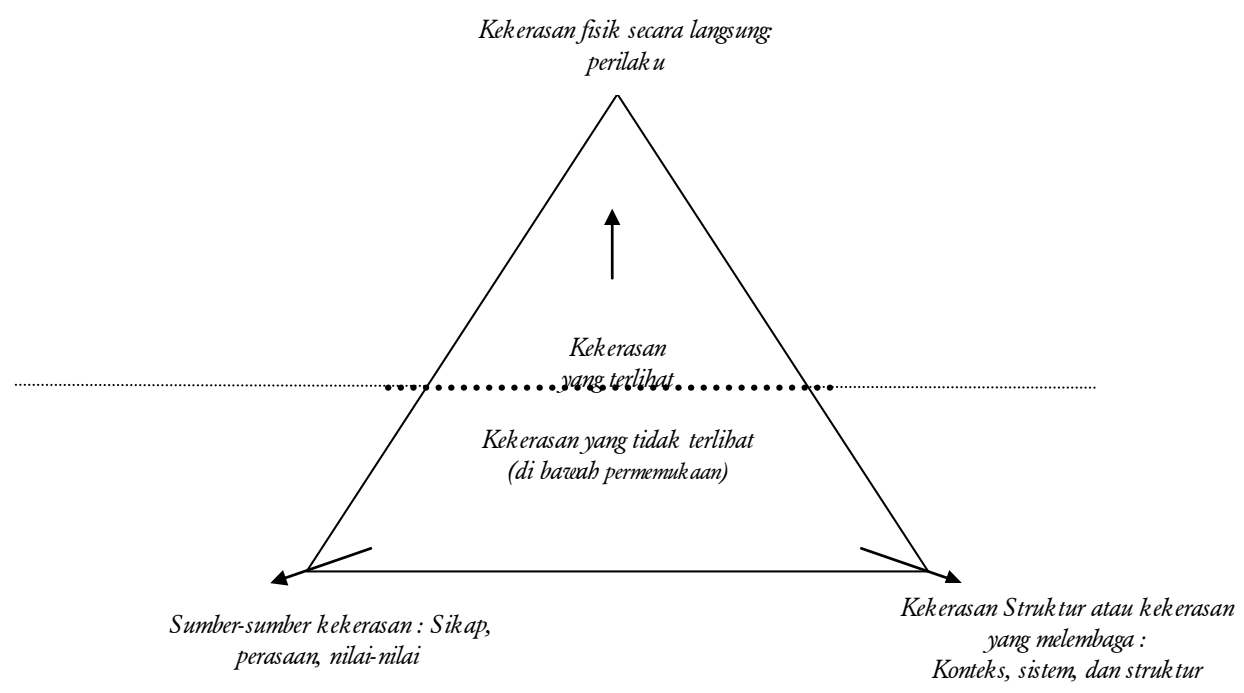

\section{Gambar 1: Hubungan antara Kekerasan Langsung, Struktural dan Kultural Sumber: Simon Fisher, et.al, 2001}

tanpa syarat, tetapi kekerasan tidak pernah dapat dihilangkan. Kekerasan menghasilkan efek demonstratif berupa reaksi kekerasan yang beruntun. Gerakan dan aksi anti kekerasan sekalipun seringkali tergelincir menjadi gerakan dan aksi kekerasan. Kekerasan makin menjadi lingkaran setan, mengikat, dan kian inheren dengan setiap perilaku manusia, komunitas, dan bangsa-bangsa. Alhasil, umat manusia seolah-olah tidak mampu melepaskan diri dari tindak kekerasan bahkan dianggap sebagai suatu keharusan atau sebagai pilihan tanpa alternatif.

Dalam konteks sistem pendidikan nasional, beberapa analisa bisa diajukan: pertama, kekerasan dalam pendidikan muncul akibat adanya pelanggaran yang disertai dengan hukuman, terutama fisik. Jadi, ada pihak yang melanggar dan pihak yang memberi sanksi. Bila sanksi melebihi batas atau tidak sesuai dengan kondisi pelanggaran, maka terjadilah apa yang disebut dengan tindak kekerasan. Selain itu, kekerasan dalam pendidikan tidak selamanya fisik, melainkan bisa berbentuk pelanggaran atas kode etik dan tata tertib sekolah. Kedua, kekerasan dalam pendidikan bisa diakibatkan oleh buruknya sistem dan kebijakan pendidikan yang berlaku. Muatan kurikukum yang hanya mengandalkan kemampuan aspek kognitif dan mengabaikan pendidikan afektif menyebabkan berkurangnya proses humanisasi dalam pendidikan. Ketiga, kekerasan dalam pendidikan dipengaruhi oleh lingkungan masyarakat dan tayangan media massa yang memang belakangan ini kian vulgar dalam 
menampilkan aksi-aksi kekerasan. Keempat, kekerasan bisa merupakan refleksi dari perkembangan kehidupan masyarakat yang mengalami pergeseran cepat, sehingga meniscayakan timbulnya sikap instant solution maupun jalan pintas; dan, kelima, kekerasan dipengaruhi oleh latar belakang sosial ekonomi pelaku. ${ }^{6}$

Tindak kekerasan di dunia pendidikan acap kali mendapat pembenaran dari masyarakat bahkan orang tua dari peserta didik karena menganggap tindak kekerasan tersebut sebagai bagian dari proses pendidikan. Padahal kenyataannya segala bentuk kekerasan akan berdampak pada konsentrasi, persepsi dan perilaku dari para korban. ${ }^{7}$ Kekerasan di institusi pendidikan biasanya merupakan manifestasi dari pola asuh otoritarian. Pola asuh ini bertujuan untuk menentukan, mengontrol dan menilai tingkah laku dan sikap-sikap anak sesuai dengan aturan-aturan yang telah ditentukan, khususnya standard-standard absolut mengenai perilaku. Dampak pola pengasuhan otoritarian ini adalah anak menjadi penakut, cemas atau gelisah, suka murung, tidak bahagia, mudah tergganggu dan suka mengganggu, permusuhan secara pasif dan menggunakan tipu daya, mudah stres atau tegang, pemarah dan menarik diri dari masyarakat, serta tidak terarah. ${ }^{8}$

Realitas kekerasan yang telah membudaya di lingkungan pendidikan perlu disikapi dengan kritis. Identifikasi terhadap jenis dan motif tindak kekerasan ini mutlak dilakukan untuk memutus mata rantai atau sekedar mengurangi dampak dari tindakan destruktif ini. Tindak kekerasan yang dilakukan, baik

\footnotetext{
${ }^{6}$ Rahmad Assegaf, Pendidikan Tanpa Kekerasan, (Yogyakarta: Tiara Wacana, 2004), hal. 3-4.

${ }^{7}$ Julie L. Crouch, Joel S. Milner dan Cynthia Thomsen dalam hasil penelitiannya yang berjudul "Childhood Physical Abuse, Early Social Support, And Risk For Maltreatment: Current Social Support As A Mediator Of Risk For Child Physical Abuse" menyatakan bahwa "Childhood physical abuse and early social support covaried, such that receipt of physical abuse was associated with lower levels of perceived early social support. Early support, but not child physical abuse, had an indirect effect (i.e., through current support) on child physical abuse risk. More specifically, levels of early support were directly related to adult perceptions of support, and adult perceptions of support were inversely associated with child physical abuse risk. Childhood physical abuse was directly related to child physical abuse risk. Low levels of early support may impact risk for child physical abuse by affecting perceptions of others as supportive in adulthood. The receipt of physical abuse in childhood, however, does not appear to impact perceptions of support in adulthood. Research is needed to identify additional factors that may explain the association between receipt of physical abuse in childhood and increased risk of child physical abuse in adulthood", dalam Jurnal Child Abuse and Neglect Vol. 25 /1, Januari (Washington: NCJRS, 2001), hal. 93 - 107.

${ }^{8} \mathrm{John}$ Th Ire, mengutip penelitian Baumrind dalam Lerner \& Hullsch, dalam Anakmu Bukanlah Anakmu, wrew.indomedia.com/poskup/2005/11/09/edisi09/0911pin1.htm diakses 12 Desember 2014, Pukul: 20.35 WIB
} 
oleh pendidik ataupun peserta didik, sering kali berbeda akar, jenis dan motifnya. Perbedaan ini tentu membutuhkan solusi penyelesaian yang berbeda pula. Penyamarataan metode penyelesaian sejatinya justru akan dapat akan memperparah penyelesaian problem akut ini. Identifikasi kekerasan dalam pendidikan dapat ditinjau dalam perspektif tingkatannya, perilaku ini dapat dibedakan menjadi tiga kelompok. Pertama, kekerasan tingkat ringan, yakni berupa potensi kekerasan (violence as potential). Pada tingkat ini kekerasan biasanya dilakukan tertutup (convert), kekerasan defensif, unjuk rasa, pelecehan martabat, dan penekanan psikis. Kedua, kekerasan tingkat sedang, yang berupa prilaku kekerasan dalam pendidikan itu sendiri (violence in education). Indikator kekerasan tingkat sedang ini mencakup: kekerasan terbuka (overt), terkait dengan fisik, pelanggaran terhadap aturan sekolah atau kampus, serta membawa simbol dan nama sekolah. Ketiga adalah kekerasan tingkat berat, yakni perilaku kekerasan yang mengarah pada tindakan kriminal (criminal action). Pada tingkat ini kekerasan berbentuk tindak ofensif, ditangani oleh pihak yang berwajib, ditempuh oleh jalur hukum, dan berada diluar ruang lingkup sekolah yang berwenang.

Selain klasifikasi dan bentuk-bentuk kekerasan berdasarkan tingkatannya diatas, kekerasan juga dapat digolongkan menjadi tiga kelompok secara garis besar. Pertama, kekerasan fisik, kekerasan model ini tergolong dalam kekerasan yang berat dan mencederai. Pemukulan, penyerangan terhadap korban, menghukum dengan menekankan pada fisik seseorang, sampai yang paling ekstrim adalah membunuh atas dasar penegakan aturan yang dilakukan terlalu berlebihan merupakan salah satu contoh kecil dari kekerasan fisik ini. Kekerasan fisik biasanya dilakukan secara individu ataupun berkelompok.

Kedua, kekerasan psikis. Kekerasan Psikis ini biasanya terjadi melalui kata-kata, baik kata-kata pedas, sinis, atau hinaan. Bentuk kekerasan psikis, misalnya, dengan melontarkan umpatan atau kalimat bully yang lain. Kekerasan psikis dapat mengakibatkan pengkerdilan potensi yang kemudian akan sangat berdampak pada pertumbuhan dan proses dialektika pengetahuan di dalam lingkup pendidikan.

Ketiga, adalah kekerasan simbolik. Diantara dua model kekerasan diatas, kekerasan simbolik adalah kekerasan yang kasat mata, tak tampak tapi berdampak besar. Konsep kekerasan simbolik pada umumnya digunakan untuk menjelaskan mekanisme yang digunakan kelompok elit atau kelompok kelas atas yang mendominasi struktur sosial untuk "memaksakan" ideologi, budaya, kebiasaan, atau gaya hidupnya kepada kelompok kelas bawah yang didominasinya. Pendidikan digunakan sebagai "medan perang" dengan berbagai 
strategi dan mekanisme untuk membangun paradigma kelas bawah agar mereka senantiasa mengakui dan menjadi bagian yang "dipaksakan" untuk mengikuti alur kehidupan masyarakat atas.

Kekerasan yang terjadi di institusi pendidikan, yang selama ini dikenal sebagai tempat penanaman nilai-nilai luhur yang berbasis humanisme dan rasional, menjadi kian terkesampingan dan terasing dari hekekatnya akibat salah pola asuh dan budaya amuk yang lekat dengan penindasan. Oleh sebab itu, pemutusan terhadap mata rantai tindak kekerasan perlu segera diupayakan agar dehumanisasi di dalam dunia pendidikan tidak terus berlangsung.

\section{Hak Anak Dalam Penddikan}

Konvensi Hak Anak (Convention on the Rights of the Child, CRC) menyebutkan bahwa pendidikan adalah hak setiap individu dan pendidikan seharusnya membantu anak dalam mengembangkan setiap kepribadian, bakat dan kemampuan mental dan fisiknya hingga tahap perkembangan sepenuhnya. ${ }^{10}$ Selaras dengan konvensi tersebut, Universal Declaration of Human Rights juga telah menyebutkan bahwa setiap individu berhak mendapatkan pendidikan dan pendidikan hendaknya diarahkan untuk mengembangkan secara utuh kepribadian manusia dan memperkokoh penghormatan terhadap HAM dan kebebasan asasi. Pendidikan hendaknya mendorong saling pengertian, toleransi, dan persahabatan antar berbagai bangsa tanpa memandang perbedaan ras dan agama, dan meningkatkan kegiatan PBB untuk memelihara perdamaian dunia. ${ }^{11}$

Secara khusus, konvensi tersebut menyebutkan bahwa setidaknya terdapat empat prinsip dasar dalam menyelenggarakan pendidikan berbasis pada hak anak. Pertama, non-discrimination, yakni penyelenggaraan pendidikan anak yang bebas dari segala macam diskriminasi, baik diskriminasi etnis, agama, jenis kelamin, ekonomi, keluarga, bahasa dan kelahiran serta kedudukan anak dalam status keluarga. Kedua, the best interests of the child, yakni pemenuhan terhadap hak anak menjadi dasar dan pertimbangan utama segala bentuk kebijakan dan tindakan yang dilakukan oleh lembaga-lembaga pendidikan, kesejahteraan sosial, lembaga peradilan, badan legislatif, dan yudikatif. Ketiga, the right to life, survival and development. Hak atas kelangsungan hidup dan perkembangan setiap anak harus diakui dan dijamin oleh setiap negara, pemerintah, masyarakat, keluarga dan orangtua. Lebih lanjut, CRC menekankan arti penting hak

${ }^{9}$ Nanang Martono, Kekerasan Simbolik di Sekolah; Sebuah Ide Sosiologi Pendidikan Pierre Bourdieu (Depok: PT Rajagrafindo Persada, 2012), hal. 5

${ }^{10}$ Libat Konvensi Hak Anak (KHA) pasal 29

${ }^{11}$ Lihat the Universal Declaration of Human Right, pasal 1 dan 2 
pengakuan serta jaminan terhadap kelangsungan hidup dan perkembangan anak, dengan menyatakan bahwa setiap negara peserta mengakui bahwa setiap anak memilki hak yang melekat atas kehidupan (inherent right to life) dan setiap negara peserta secara maksimal mungkin akan menjamin kelangsungan hidup dan perkembangan anak (survival and development of child)"; dan Keempat, respect for the viezes of the child, yakni penghargaan dan penghormatan atas pendapat anak adalah sebuah bentuk penghormatan atas hak-hak anak untuk turut berpartisipasi dan menyatakan pendapat dalam pengambilan keputusan, khususnya terkait hal-hal yang terkait dengan kehidupannya.

Konvensi Anti Penyiksaan (Convention Anti Torture), konvensi yang mengatur salah satu bentuk manifestasi tindak kekerasan berupa penyiksaan, perlakuan atau penghukuman lain yang kejam, dan merendahkan martabat manusia, ${ }^{12}$ menyatakan bahwa kekerasan langsung menjadi tanggung jawab setiap pelaku (individual responsibility), dalam arti bahwa setiap individu yang melakukan tindak kekerasan akan mendapatkan hukuman (punishment) sesuai dengan ketentuan hukum pidana yang berlaku di negara tersebut (ius constitutum). Sedangkan kekerasan struktural dan kekerasan kultural menjadi bentuk tanggung jawab negara (state responsibility) dalam rangka mengimplemetasikan ketentuan-ketentuan dalam konvensi tersebut yang bermuara pada pemberlakukan sistem hukum pidana (criminal justice system). Jika terdapat ketidaksesuaian dengan ketentuan konvensi maka memerlukan perubahan (amandement) atau desain tata hukum baru (ius constituendum) melalui upaya kriminalisasi dan atau dekriminalisasi substansi hukum pidana sehingga semangat dan jiwa konvensi tersebut termuat dalam ketentuan di dalam sistem hukum pidana akan diberlakukan kemudian.

Negara Republik Indonesia, sebagai salah satu peserta konvensi dan telah meratifikasi konvensi-konvensi internasional tersebut melalui sejumlah perundang-undangan, berkewajiban mengupayakan dengan seluruh sumber daya politik, ekonomi dan sosial yang dimiliki untuk melindungi dan menjamin setiap hak anak, terutama dari segala bentuk tindak kekerasan terhadap anak, baik fisik, mental maupun seksual, karena segala bentuk kekerasan terhadap anak merupakan salah satu bentuk pelanggaran serius terhadap hak asasi dan martabat anak, ${ }^{13}$ serta mencegah munculnya tindak kekerasan di dalam wilayah

${ }^{12}$ Konvensi Menentang Penyiksaan dan Perlakuan atau Penghukuman Lain yang Kejam, Tidak Manusiawi dan Merendabkan Martabat Manusia merupakan elaborasi dari Pasal 5 Deklarasi Universal HAM dan Pasal 7 Kovenan Hak Sipil dan Politik . Libat Konsideran Konvensi.

${ }^{13}$ Kekerasan Anak dalam Pendidikan :Akar Masalah, Locus, Korban, Pelaku, dan Kerwajiban Negara, http://www.ypha.or.id/web/wo-content/uploads/2010/06/Kekerasan-di-sekolah.doc. diakses 2 Februari 2015, Pukul: 20.00 WIB

LITERASI, Volume V, No. 2 Desember 2014 
hukumnya melalui regulasi yang ada sedemikian rupa sehingga para pelaku tindak kekerasan tersebut dapat diproses sesuai dengan regulasi hukum pidana yang berlaku. ${ }^{14}$

\section{Pendidikan Berbasis Hak Anak; Meretas Jalan Sekolah Ramah untuk Anak}

Wahono menggambarkan bahwa bangunan pendidikan selama ini justru cenderung turut memperlancar praktik-praktik kekerasan. Menurutnya selama ini peserta didik secara simbolik peserta didik diilustrasikan sebagai "korban" dari bangunan pendidikan kita selama ini, strata peserta didik berada pada strara paling bawah. ${ }^{15}$ Peserta didik menjadi obyek langsung dari kurikulum yang didukung oleh kerangka dan pranata pendidikan. Model pendekatan yang "dilanggengkan" dalam bangunan pendidikan kita saat ini adalah model top down, dari atas ke bawah, yang cocok diterapkan pada sistem pendidikan militer - disiplin seragam, ketat ideologi, disiplin perintah tanpa boleh banyak bertanya. Sebagai konsekuensinya, metode pendidikan yang dipakai adalah "metode anjing". Sebagaimana tuan dan peliharaannya, anjing dididik oleh tuannya dengan sistem reward dan punishment agar si anjing menjadi setia dan tunduk pada tuannya (lihat Gambar. 2).

Lebih jauh, Wahono juga mengilustrasikan bahwa model pendekatan yang seharusnya diterapkan dalam bangunan sistem pendidikan kita adalah model pendekatan bottom up, yang menempatkan peserta didik sebagai pusat seluruh aktivitas pendidikan. Pendekatan ini tidak menjadikan kerangka dan pranata pendidikan, termasuk penyelenggara pendidikan sebagai penentu pendekatan, sistem, dan metode pendidikan. Melainkan dibangun berdasarkan kebutuhan peserta didik atau konteks keberadaan peserta didik. Bangunan pendidikan semacam ini disebutnya dengan pendidikan "sistem petani". Sebagaimana petani menghadapi dan memperlakukan tanamannya sesuai dengan konteks kehidupannya di alam. Metode pembelajaran dalam sistem semacam ini disebutnya dengan pendidkan "metode ayam", sebagaimana induk ayam memperlakukan anak-anaknya. Induk ayam tidak pernah mendikte anak ayam agar setia. Sang induk menginginkan kedewasaan dan kemandirian anak-anaknya. Pendekatan pendidikan yang bottom up dengan sistem petani dan metode ayam akan mampu menciptakan pendidikan tanpa kekerasan. ${ }^{16}$

${ }^{14}$ Ibid.

${ }^{15}$ Francis Wabono, Kekerasan dalam Pendidikan : Sebuah Tinjauan Sosio-Ekonomi Didaktika, dalam Gelombang Perlawanan Rakyat : Kasus-Kasus Gerakan Sosial di Indonesia, Yogyakarta, Insist Press, 2003, hal. 239

${ }^{16}$ Ibid., 241 


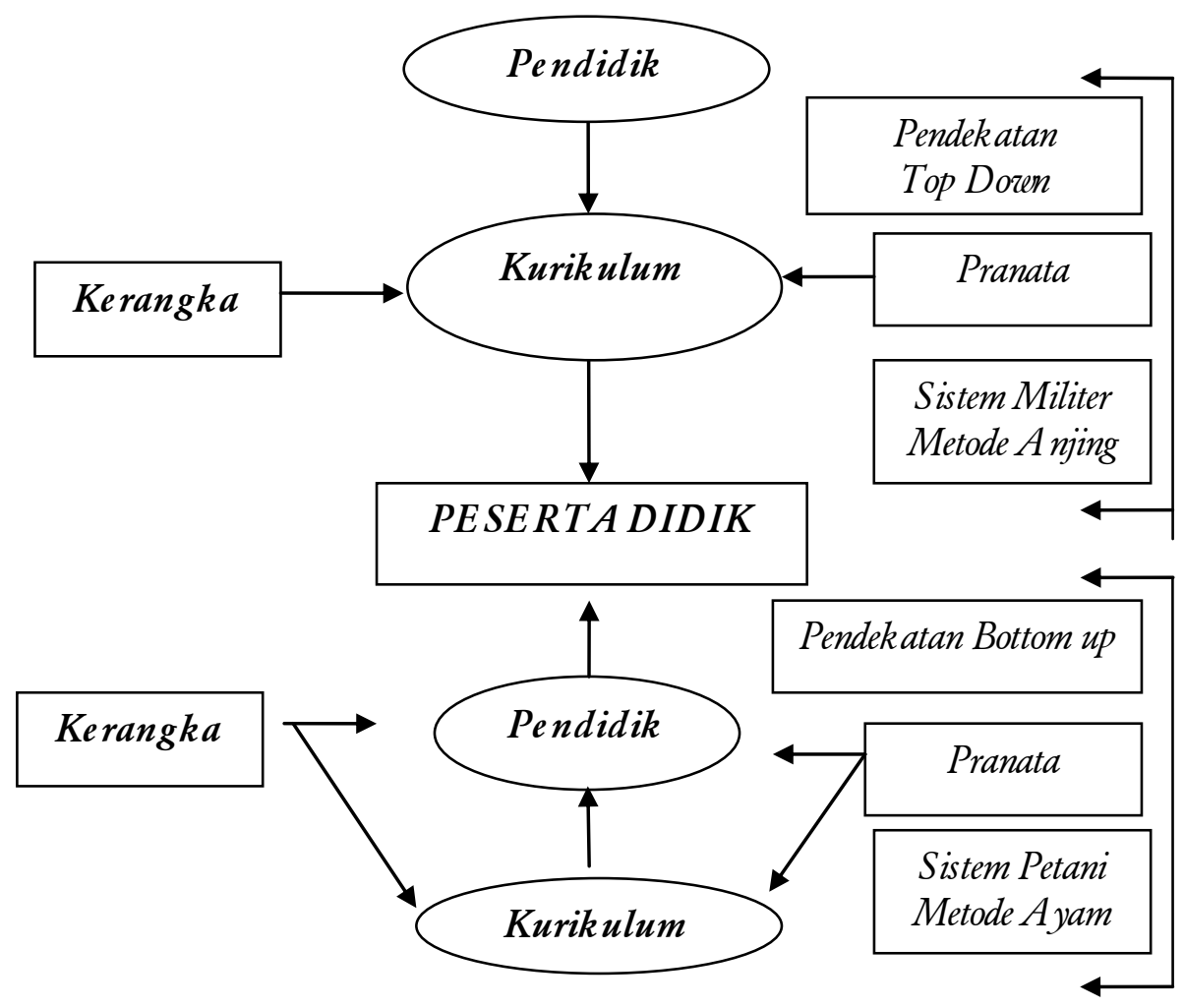

Gambar 2 : Pendidikan di Indonesia : Kini dan Mendatang

Sumber : Francis Wahono, 2003

Felisa Tibbitts menawarkan sebuah kerangka kurikulum dan pedagogis dalam bingkai pendidikan berbasis hak anak secara umum. Kerangka ini disandarkan pada kerangka yang dikembangkan oleh UNICEF. ${ }^{17}$

1) Pengakuan terhadap setiap hak anak.

2) Memandang anak secara keseluruhan dalam sebuah konteks yang luas.

3) Terpusat pada anak.

4) Sensitivitas pada gender dan ramah pada anak perempuan.

5) Memajukan hasil pembelajaran yang berkualitas.

6) Memberikan pendidikan berdasarkan realitas kehidupan anak-anak.

7) Bertindak untuk menjamin terjadinya inklusi, rasa hormat, dan kesetaraan kesempatan bagi semua anak.

${ }^{17}$ Felisa Tibbitts, "Editorial Tamu: Pendekatan Berbasis Hak Asasi atas Pendidikan" dalam EENET Asia Newsletter Enabling Education Network Asia Edisi ke-4, Juni 2007, hal. 7-8. http://www.idp-europe.org/eenet-asia/eenet-asia-4-ID/page7.php 
8) Memajukan hak-hak dan tangung jawab siswa dalam lingkungan sekolah serta bekerja untuk umum dalam masyarakat mereka secara luas.

9) Meningkatkan kemampuan, moral, komitmen dan status pengajar dengan memastikan bahwa para pengajar mendapatkan pelatihan, pengakuan dan kompensasi yang memadai.

10)Berpusat pada keluarga.

Jika kita amati lebih jauh, kerangka ini selaras dengan indikator penyelenggaraan sistem pendidikan oleh sebuah institusi atau negara yang mampu menjamin hak-hak setiap warga negaranya, indikator tersebut dalam Komentar Umum PBB Nomor 13 tentang hak atas pendidikan, yakni:

Ketersediaan lembaga, artinya institusi, infrastruktur, fasilitas sekolah dan program-program pendidikan tersedia dalam jumlah yang memadai untuk menjamin hak anak mendapatkan pendidikan secara nyaman dan aman. Misalnya, negara harus mengawasi bahwa bangunan sekolah menyediakan fasilitas sanitasi yang aman, air bersih, dan tersedianya guru yang berkualitas.

Aksesibilitas, artinya setiap orang punya akses atas lembaga, institusi dan program-program pendidikan dapat diakes secara ekonomis. Selain itu, negara juga harus memastikan bahwa sekolah bisa diakses oleh semua orang tanpa adanya diskriminasi.

Akseptibilitas, artinya format, substansi pendidikan seperti kurikulum, metode pengajaran mesti berkesesuaian dengan situasi, kondisi dan budaya siswa. Bentuk dan isi pendidikan, termasuk kurikulum dan metode pengajaran, harus dapat sesuai dengan budaya dan konteks lokal.

Adaptibilitas, artinya pendidikan harus fleksibel, dapat disesuaikan dengan perubahan situasi masyarakat yang mempunyai keragaman sosial dan budaya. Sekolah harus mampu beradaptasi dengan budaya dan konteks lokal dalam proses pembelajaran dan dalam penyusunan kurikulum.

Kewajiban negara untuk menghormati, melindungi dan memenuhi Hak Pendidikan Anak juga diatur dalam Undang-UndangNomor 11 Tahun 2005 tentang Ratifikasi Kovenan Hak Ekonomi, Sosial dan Budaya. Penerapan Undang-Undang ini memastikan para pemangku kepentingan untuk menghormati ketersediaan pendidikan dengan tetap menghormati partisipasi masyarakat dalam menyelenggarakan pendidikan; melindungi aksesibilitas semua anak, termasuk anak berkebutuhan khusus; menerapkan Standar Pelayanan Minimal yang memastikan pendidikan diselenggarakan relevan secara budaya termasuk bagi kelompok minoritas dan penduduk asli; memenuhiketersediaan pendidikan dengan aktif mengembangkan sekolah 
yang aman, bersih, sehat, hijau, inklusif dan nyaman bagi perkembangan fisik, kognisi dan psikososial anak perempuan dan anak laki-laki termasuk anak dengan kebutuhan khusus; memenuhi ketersediaan pendidikan melalui pengembangan kurikulum yang mencerminkan kebutuhan semuaanak untuk tumbuh kembang di dunia yang sedang berubah.

Upaya penjaminan dan pemerataan kesempatan pendidikan, peningkatan mutu serta relevansi dan efisiensi manajemen pendidikan untuk menghadapi tantangan sesuai dengan tuntutan perubahan kehidupan lokal, nasional, dan global perlu dilakukan melalui pembaharuan pendidikan berbasis hak anak (PBHA)secara terencana, terarah, dan berkesinambungan. Sehubungan dengan hal tersebut, kerangka acuan pengembangan secara teknis penerapan pendidkan berbasis hak anak (PBHA) disusun sebagai berikut:

\section{Pengembangan Kurikulum}

Pengembangan kurikulum melalui pendidikan berbasis hak anak (PBHA) dikembangkan berlandaskan asas relevansi pendidikan dengan budaya, sosial dan bahasa dalam upaya pengembangan karakter bangsa sejak usia dini di sekolah. Proses pembelajaran dilakukan secara inspiratif menyenangkan, interaktif, menantang, memotivasi dan memberi ruang bagi prakarsa kreativitas dan kemandirian anak sesuai minat, bakat dan kebutuhannya untuk tumbuh kembang. Dukungan orang tua dalam menciptakan lingkungan inklusif dan ramah bagi pembelajaran anak di rumah sangat penting dalam pengembangan kurikulum berbasis hak anak. Media dan lingkungan diharapkan pula secara proaktif mendukung tersedianya sumber belajar yang "ramah" anak.

\section{Sarana dan Prasarana}

Peraturan Kepala BNPB Nomor 4 Tahun 2012 tentang Pedoman Penerapan Sekolah Aman dari Bencana yang disusun oleh BNPB bersama K/L/D/I melengkapi Peraturan Menteri Pendidikan Nasional Nomor 24 Tahun 2007 tentang Standar Sarana dan Prasarana untuk SD/MI, SMP/MTs, SMA/MA dan lampirannya yang mengatur lebih rinci mengenai persyaratan kesehatan, keselamatan, kemudahan termasuk kelayakan bagi penyandang cacat, kenyamanan dan keamanan.

Hal ini sejalan dengan ketentuan dalam Undang-Undang Nomor 20 Tahun 2003Pasal 45 Ayat 1 yang menyatakan: "Setiap satuan pendidikan formal dan nonformal menyediakan sarana dan prasarana yang memenuhi keperluan pendidikan sesuai dengan pertumbuhan dan perkembangan potensi fisik, kecerdasan intelektual, sosial, emosional, dan kejiwaan peserta didik". 


\section{Pendidik dan Tenaga Kependidikan}

Guru dan tenaga kependidikan di sekolah tersedia dalam jumlah yang cukup dan tepat dengan kondisi kerja dan kompensasi yang layak sangat diperlukan dalam upaya membangun gerakan aman, sehat, hijau, inklusi dan ramah anak dengan dukungan keluarga di sekolah. Mekanisme dukungan dan pengawasan bagi pendidik dan tenaga kependidikan senantiasa mempertimbangkan prinsip kepentingan terbaik anak.

Pendidik selain diperankan oleh guru, juga diperankan oleh orang tua di dalam rumah tangga dan masyarakat. Orang tua merupakan pendidik pertama dan utama bagi anak sebagaimana dinyatakan dalam Pasal 7 UU No. 20 Tahun 2003 tentang Sistem Pendidikan Nasional yang berbunyi: (1) Orang tua berhak berperan serta dalam memilih satuan pendidikan dan memperoleh informasi tentang perkembangan pendidikan anaknya; (2) Orang tua dari anak usia wajib belajar, berkewajiban memberikan pendidikan dasar kepada anaknya.

\section{Pengelolaan}

Pengelolaan sumber daya pendidikan mulai dari kebijakan dan anggaran teridentifikasi dengan jelas dan dapat digunakan untuk menerapkan kesempatan belajar yang sesuai dengan tumbuh kembang dan perlindungan anak dalam semua tahap pelaksanaannya.

Pemantauan dilaksanakan secara berkala terhadap kegiatan pendidikan dan kebutuhan belajar pada usia anak termasuk dalam situasi darurat melalui Evaluasi Diri Sekolah yang sudah diatur dalam Sistem Penjaminan Mutu Pendidikan oleh Tim Pengembang Sekolah dilaksanakan dengan senantiasa mempertimbangkan kepentingan terbaik anak. Evaluasi pendidikan dilaksanakan secara sistematis dan tidak memihak dalam upaya memperbaiki kualitas layanan pemenuhan hak pendidikan anak dan meningkatkan akuntabilitas pendidikan

\section{Pembiayaan}

Penentuan komponen pembiayaan dan sumber pendanaan pendidikan melibatkan secara aktif para pemangku kepentingan pendidikan termasuk anak. Pemerintah, pemerintah provinsi, dan pemerintah kabupaten/kota juga memberikan kepastian hukum bagi pihak-pihak yang masih melakukan berbagai pungutan liar yang menjadi hambatan program penuntasan wajib belajar pendidikan dasar.

Pembiayaan pendidikan telah diatur dalam UUD Negara Republik Indonesia 1945 dan Amandemen IV yang menyatakan bahwa: "Setiap warga negara berhak mendapat pendidikan; setiap warga negara wajib mengikuti 
pendidikan dasar dan pemerintah wajib membiayainya; pemerintah dan pemerintah daerah memprioritaskan anggaran pendidikan sekurang-kurangnya dua puluh persen dari Anggaran Pendapatan dan Belanja Negara (APBN) serta dari Anggaran Pendapatan dan Belanja Daerah (APBD) untuk memenuhi kebutuhan penyelenggaraan pendidikan nasional".

Selain itu, peran serta masyarakat sebagaimana diatur dalam UU No. 20 Tahun 2003 Pasal 8 menyatakan: "Masyarakat berhak berperan serta dalam perencanaan, pelaksanaan, pengawasan, dan evaluasi program pendidikan", dan Pasal 9 menyatakan: "Masyarakat berkewajiban memberikan dukungan sumber daya dalam penyelenggaraan pendidikan".

\section{KESIMPULAN}

Pendidikan berbasis hak anak merupakan salah satu upaya pemenuhan dan perlindungan hak anak atas pendidikan, penciptaan mekanisme pengamanan untuk menjamin hak-hak anak agar terbebas dari berbagai bentuk tindakkekerasan, dan penjaminan hak-hak anak untuk mendapatkan pendidikan dan lingkungannya yang aman dan tepat, baik dalam hal proses maupun isi, yang mampu memenuhi standard pendidikan dan menghormati konteks serta budaya lokal tempat sekolah tersebut berada.

\section{DAFTAR PUSTAKA}

Arna, Antarini, Analisis Hasil Konsultasi Anak Regional dan Nasional: Kekerasan Terhadap Anak, Jakarta: YPHA. 2005.

Felisa Tibbitts, "Editorial Tamu: Pendekatan Berbasis Hak Asasi atas Pendidikan" dalam EENET asia newsletterEnabling Education Network Asia Edisi ke-4, Juni 2007, http://www.idp-europe.org/eenet-asia/eenetasia-4-ID/page7.php

Francis Wahono, Kekerasan dalam Pendidikan: Sebuah Tinjauan Sosio-

Ekonomi Didaktika, dalam Gelombang Perlawanan Rakyat: Kasus-Kasus Gerakan Sosial di Indonesia, Yogyakarta, Insist Press, 2003

Johan Galtung, Studi Perdamaian: Perdamaian dan Konflik Pembangunan dan Peradaban, (Surabaya: Pustaka Eureka, 2003).

John Th Ire, mengutip penelitian Baumrind dalam Lerner \& Hullsch, dalam Anakmu Bukanlah Anakmu, www.indomedia.com/poskup/2005/11/09/ edisi09/0911pin1.htm diakses 12 Desember 2014, Pukul: 20.35 WIB 
Julie L. Crouch, Joel S. Milner dan Cynthia Thomsen , "Childhood Physical Abuse, Early Social Support, And Risk For Maltreatment: Current Social Support As A Mediator Of Risk For Child Physical Abuse”, dalam Jurnal Child Abuse and Neglect Vol. 25 /1, Januari (Washington: NCJRS, 2001). Justin Sihombing, Kekerasan terhadap Masyarakat Marjinal, Yogyakarta, Penerbit Narasi 2005.

Komaruddin Bagja Arjawinangun, "Kini Sekolah Bukan Tempat Aman untuk Anak", http://metro.sindonews.com/read/936157/31/kini-sekolahbukan-tempat-aman-untuk-anak-1418308935 diakses 1 Maret 2015, pukul: 13.00 WIB

Konvensi Hak Anak (Convention on the Rights of the Child, CRC)

Nanang Martono, Kekerasan Simbolik di Sekolah; Sebuah Ide Sosiologi Pendidikan Pierre Bourdieu (Depok: PT Rajagrafindo Persada, 2012).

Rahmad Assegaf, Pendidikan Tanpa Kekerasan, (Yogyakarta: Tiara Wacana, 2004), hal. 3-4.

Simon Fisher, et.al, Mengelola Konflik: Keterampilan \& Strategi untuk Bertindak, (Jakarta: The British Council, 2001)

YPHA, Kekerasan Anak dalam Pendidikan :Akar Masalah, Locus, Korban, Pelaku, dan Kewajiban Negara, http:/ /www.ypha.or.id/web/wp-content/ uploads/2010/06/Kekerasan-di-sekolah.doc. diakses 2 Februari 2015, Pukul: 20.00 WIB 